\title{
Young Event Services: Lifestyle Or Living? Teaching Case
}

Ram Subramanian, Montclair State University, USA

Richard Peterson, Montclair State University, USA

Heidi Sulich, Montclair State University, USA

\section{YOUNG EVENT SERVICES: LIFESTYLE OR LIVING?*}

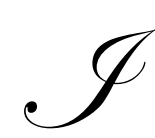

pity.

$\mathrm{t}$ was 4:30 in the morning of June 24, 2007, and Julie Young, the owner of Young Event Services (YES) was spending another late night at her desk in her home office--with no sleep. As she struggled with the variety of chores she was wrestling with, her mind wandered, partly in exasperation and partly in self-

"If I could only have about twelve more hours in a day, then I would be set. I wonder if the girls placed the orders for the baseball cubes for the golf outing on Thursday. Chris Smith said his wife was allergic to garlic. I have to look over his menu again before I kill his wife. I have the guys flying in on Wednesday. Ralph will be in by 2:00 p.m. and Ron will be picking him up. Then he will have to go back and get Timmy when he lands at 5:00 p.m. Thursday morning I have Don and Mark flying in at 9:00 a.m. just in time for tee-off. Oh! Note to self: Must call in payroll!! Jennifer Rock wanted to discuss theme ideas for her daughter's Bat Mitzvah. Now where did I put her folder? I am pretty sure it is in my brown bag I used on Monday. Nope. Not there. Oh, no, did I leave it in the car? Oh wait! I brought it inside the house on Monday and left it right on my stove. Always a safe place!

Julie could see the beginning of another day breaking though the darkness of the night outside her office window. She clenched her fists at the new dawn, hoping it would go away so she could just finish this day first. Her husband called her to bed again for the fifth time that night. For her own health, she figured she should go, even if it was just to close her eyes and to sort things out in her head. As she lay there knowing she only had two hours until she had to get the kids ready for school and it would just start all over again, it hit her.

"I'll be 45 next month, my kids are already applying to colleges, my husband will be retiring soon with his pension from the fire house, and I'll have this. 'This' being my event planning business. My office is a mess and no one would ever believe that it truly is all organized -- at least in my head. It is all a matter of time until I can find time to write it down, organize it, review it, and file it away correctly. Never in a million years did I think my hobby would turn into a passion and then would turn into a lifestyle business. I breathe, sleep, and eat event planning 25 hours a day."

Julie awoke to her husband's pager going crazy with its incredibly annoying beeping and chirping. They were calling for an additional crewmember to join another town's crew because they were short-handed. Julie's husband rolled over, looked at her, and said what he always said to her when she was up until 5:30 in the morning, "Lifestyle or living?" She gave him her usual response, "I know, I know!"

\section{THE MEETING WITH THE LAWYER}

After Julie sent her daughters off to school, she spent a short while attending to her business. She then left with her husband for their 10:30 a.m. appointment with their lawyer, Bill Sanders, to update and go over their will. As Bill was going over a set of basic questions about their finances, Julie's mind was wandering a million miles a

\footnotetext{
* This case is intended to stimulate class discussion rather than illustrate the effective or ineffective handling of a business situation. While the names of the company and the people are disguised, all events presented in the case are real.
} 
minute. For a second, then, she was caught by surprise by Bill's question addressed to her. "Have you thought about your business and what you will do with it?" "I have thought about it, but just a little. To be honest, my business has taken off right under my nose, and I have not had a minute to even make dinner! Ideally I would love to pass on my business to my daughters in hopes that they will continue with it and its success," replied Julie. "Well then, let's just take a few minutes to reflect on it, shall we? How much is your business currently worth?" asked Bill. "How much is it worth? I don't know that, but I know that last year we had revenues of $\$ 350,000$," answered Julie proudly. "But, when was the last time we went on a family vacation? If everything about the business is in your head, what are you going to pass on to our daughters?" asked Julie's husband. At that point, all three of them decided that they couldn't finalize the Young's will and agreed to meet on a later date. It was a thoughtful Julie who walked back to her car with her husband and she continued to be pensive after she dropped off her husband.

Delayed by the visit to the lawyer's office, Julie was stuck in traffic on her way to a meeting with a client. As frustrated drivers honked and yelled at the stalled traffic, Julie ruefully admitted to herself that she had to take both her husband's and Bill Sanders' admonishment seriously. "Maybe the stalled traffic is an apt metaphor for YES. We are moving forward, albeit at a pace slower than where I pictured YES ten years ago. Is it because of my lack of organization? Maybe I need to take a serious look at the business plan that my assistant Madison Beech did for her college class," reflected Julie.

\title{
JULIE'S HISTORY
}

Julie Young graduated from Pace University in 1984 with a bachelor's degree in communications. The day after graduation she started working at a well-known public relations firm in New York City. In her job, Julie dealt with a variety of event planning companies, corporate firms, and small businesses and acquired a few friends along the way. A few years into the business she realized that a big PR firm was not what she was looking for. She wanted to be involved in something a little smaller and more personable. She used her contacts and networked her way to another job. She fell into the hands of a well-known catering company in New Jersey. She took on the role of a client representative and after a few years of building up her own client base, she teamed up with a sous chef, Amy Barnes, to begin their own catering business. Julie had an informal agreement with Amy whereby Amy was the exclusive chef for YES. Amy's main concerns were only chef-related concerns. Julie handled everything else. During the last fifteen years, YES had grown into a well-regarded event planning company with a number of repeat clients.

Before Julie jumped head first into the business she did a bit of market research and was encouraged by what she found.

\section{THE MARKET AND COMPETITION*}

\author{
Special events included: \\ $\circ \quad$ Celebrations (weddings, reunions, birthdays, anniversaries) \\ $\circ \quad$ Educational events (meetings, conferences, graduation) \\ $\circ \quad$ Promotions (product launches, fashion shows, political rallies) \\ $\circ \quad$ Commemorations (civic events, memorials)
}

Worldwide annual spending for special events was estimated to be over $\$ 500$ billion. The convention and trade show organizer business was estimated to be $\$ 10.1$ billion in 2003 with over 1 million meetings held per year in the U.S.

The competition came from in-house services, especially through corporate planners, independent event planning services, or companies dominant in some aspect of event planning (e.g., florists, rental companies, caterers). There were 43,000 meeting and convention planners in 2004 in the U.S.: $32 \%$ worked for corporations or

\footnotetext{
${ }^{*}$ This section is based on the references listed at the end of the case
} 
convention/trade show firms, $30 \%$ worked for religious or professional organizations, $17 \%$ worked for hotels, $9 \%$ worked for education, $6 \%$ worked for government, and $6 \%$ were self-employed.

Event planning fees were charged in a number of ways:

- Percentage of the total budget,

$\circ \quad$ Fee for individual services (cost-plus $15 \%$ was typical),

○ By the hour, or

$\circ \quad$ Commissionable rates and add-ons (handling fee for each service provided).

Planning fees varied by market segment served (corporate was more lucrative than social), geographic location (the northeast was more lucrative than, say, the south west), and experience and reputation was key. Fiftyfive percent of event planners earned between $\$ 55,000$ and $\$ 100,000$ per year. Gross profit margin for independent planning firms averaged $30-40 \%$. Typically personal clients had at least $\$ 60,000$ in annual household income. A population base of at least 50,000 residents was needed to support an event planning service.

Professional certifications (Certified Special Events Professional, Certification in Meeting Management, Certified Meeting Professional, Certified Global Meeting Partner, and Destination Management Certified Professional) assured customers of someone well experienced in the field.

There were two markets for event planning services: corporate and social. The term "corporate" included not only companies but also charities and nonprofit organizations. Charities and nonprofit organizations hosted gala fundraisers, receptions and athletic competitions, to increase their public support base and raise funds. Thousands of these events occurred each year. Companies hosted trade shows, conventions, company picnics, holiday parties and meetings for staff members, board members or stockholders. Social events were otherwise known as personal events, regional events, and event services (e.g., catering, photography, costumes).

Factors such as the area in which the business was located, the cost of living in the area a business served and whether the event planner worked from home or rented office space affected the income potential of the event planning business.

Most event planning marketing, especially for independent planners, was by networking and word-ofmouth. Dealing with competition was typically handled through networking. Networking helped the event planning business in two ways. Satisfied current customers referred the event planner to others or used the service themselves in the future. The norm in the business was that a successful event gained 25 new clients. In contrast, an unsuccessful event lost the event planner 35 potential clients. Furthermore, networking with hotels, caterers, and event spaces gave the event planner the chance to meet some of the people whose services the event planner may need for future events. Although networking and word-of-mouth were the most common industry strategies for acquiring clients, traditional forms of advertising were also used.

The market for social events, especially birthdays and anniversaries, was expected to continue to increase over the next few years, as baby boomers matured. This group had children getting married, parents celebrating golden anniversaries, and their own silver wedding anniversaries to commemorate.

\section{BUSINESS PROCESSES OF YES}

\section{Mission}

With total quality management, YES' mission was to reach the top of the event planning industry in the New York City/Northern New Jersey area. YES intended to strive to be the number one choice of event management. The goal was to stay on top of the industry and technology trends, offering consistent, predictable professionalism, while meeting each client's unique requirements. 


\section{Description Of Products And/Or Services}

In order to grow the business Julie said "Yes" to almost any event and any request. While this led to many sleepless nights, the result was a full-service event management company with expertise in weddings, special events (e.g., birthdays, retirement parties and showers), Bar/Bat Mitzvahs, and charitable golf outings. For each event YES did everything from planning the event to preparing invitations, securing and decorating the facility, preparing customized gifts for guests, managing third-parties such as bands or photographers, transporting guests, food preparation and service, and post-event clean-up. No request was too large and no detail too small for YES. Exhibits A and B present sample event timelines of major activities for large and small events.

\section{Keys To Success}

Julie Young believed that the keys to YES' success included the commitment to satisfaction and creating brand loyalty. Communication played a dramatic role in how clients perceived the business and YES workers were very well experienced with customer service. YES offered clients special one-on-one treatment that met all of their individual needs. YES' signature was convenience.

YES' product was a talked-about event which resulted from their one of a kind customer service. The YES services catered to the client's basic needs and wants. YES worked side-by-side with clients in planning and managing special occasions. Staff was also onsite the day of the event to ensure the success of the event.

Special event planners were becoming more and more of a necessity to many individuals. Whether private or public, there was a consistent need for hiring someone to handle the complicated and tedious work in putting together a special event. YES was up-to-date with all the current event changes.

The event planning industry continued to be a growing one with increasing competition. The New York City/Northern New Jersey market area had several companies that had been in the market longer with an existing client base. The overall market was split between large businesses, mostly hotels and catering facilities that did event planning as a means of selling the facility and small and regional sole proprietorships such as YES.

\section{Organizational Structure}

YES was operated mainly by Julie with some occasional part-time help from Madison, an employee she had found though the local university internship program; Kim, a woman in her mid-twenties; and, Katie, an older neighbor of Julie's who worked one or two days a week. Julie also had a Rolodex full of name of workers from bartenders, to wait staff, to drivers, to floral arrangers. YES hired these resources as needed. Business for YES was particularly high during the summer and winter holiday seasons, resulting in a large staff and large payroll during these months. April through June and October though December were considered her high season. Her revenues during those months were approximately $\$ 230,000$. January though March and then again from July though September were considered her low seasons. Revenues during those months were approximately $\$ 120,000$. Business during the low seasons consisted mainly of business and corporate affairs so staffing needs were less.

Julie had multiple roles within the company from contract to catering and decorators to disc jockeys. As the business grew, Julie began focusing on the larger clients (guest counts above 300). Kim was responsible for the smaller events and Katie was the event planner for companies and corporations.

\section{Pricing}

YES charged a consulting fee for planning the event. The fee was based on the type of event with wedding planning costing more than $\$ 10,000$ and planning for smaller events costing anywhere from $\$ 1,500$ to $\$ 3,000$.

YES bought or rented all necessary materials, from tables and chairs to food items and charged the customer the direct cost of the items plus a handling fee of $20 \%$ of the costs. 
Personnel required at an event were paid hourly ( $\$ 12 /$ hour for wait staff to $\$ 25 /$ hour for bartenders plus income taxes) and the customer was billed $\$ 30 /$ hour per person, regardless of the personnel rate of pay.

\section{Marketing And Sales}

YES targeted those in need of event planning assistance, who were most able to afford event planners, and had the least amount of time to spare for event planning. While YES primarily served the northern New Jersey area as well as New York City, they gladly served anyone in need--they never turned away a customer strictly because of distance.

Many of the clients came from "word of mouth" referrals. Clients appreciated that YES coordinated all aspects and details of events for a wide array of occasions. Referrals were a major source of new business for YES, as YES did no media advertising.

For each event, YES would first meet with their client's one-on-one to discuss the service. They discussed what the client wanted done in their event, and how they wanted it done. Customers were expected to come to YES knowing exactly what they wanted. However, there were also customers who did not have any idea what they wanted and were open to suggestions. In these instances, YES offered creative suggestions and helped the client design the event. After the customer gave YES the idea of how they envisioned their event, the rest of the work was done by YES.

\section{DECISION TIME}

Julie had gotten her third wind of the day, and decided to do a little straightening up of her office. It needed it because she had invoices lying around on the floor from 2005. It was time she tackled this office by starting with that dusty pile of papers over in the corner. "How could I not have put them away all this time"? reflected Julie. As she went though the papers one by one she stumbled upon the business plan that Madison had given her two years ago. Julie was more of a mentor to Madison, a part-time employee at YES while she was finishing her B.S. in business administration. Julie took a second look at Madison's plan just to see what Madison and her professor had recommended she do to grow YES. Julie, blew off the dust on top of the plan, opened the plan to the Executive Summary, and noticed "Table 1 - Key Recommendations to Grow YES to a Sustainable Business". (Exhibit C contains the table.)

As Julie sat back to let what she just read soak in, she realized how nice that all sounds. "Easier said then done, I bet. Where would I even start to turn my business around?" She still couldn't believe that she let her office get this messy, let alone think about taking a few steps back and asking for help. "Who would I ask for help?" She glanced back at Madison's name on the front of the business plan proposal. Madison had only has a month of school left before graduation. "I wonder... but would I even be able to afford taking steps back and spending time, effort, and money on expanding my business? Adding someone might just make things worse. If I got myself together and separated life from work, I could just get myself back on track."

Just as she was in the middle of trying to work things out in her head, her husband popped his head into her office. He knew better than to even step foot in her office for fear that he might step on a mine and blow up. "What'd ya got there pretty lady?" he asked. "Oh, just a business plan from Madison. She gave it to me a few years ago while she took a small business class. That was when I was her mentor, remember? replied Julie. "And what'd she have to say?" he asked. "Basically she told me I need a living and not a lifestyle. What does this girl know anyway? She is just 21 years old and knows only a quarter of how this business works," continued Julie. "But, could she also be right?" asked her husband. "I don't know, but if you give me sometime to get though all of these piles, I might be able to answer your question," said Julie, only half in jest.

As Julie's Blackberry tweeted with a reminder to put together her proposal for her lawyer that was due by noon tomorrow, she reflected on the two choices that Madison had presented in her business plan. 
The first was to hire a second-in-command who would free Julie to concentrate on getting new clients and be able to take time off from YES. This alternative would reduce Julie's profits because of the added salary (Julie estimated that she would have to pay the new hire around $\$ 50,000$ in annual salary) but would allow her more personal time.

The second alternative did not recommend a new hire for YES. Instead, it called for Julie to create an organization chart and clearly designate specific roles for the three employees. The idea behind this alternative was to create not only job responsibilities but also flow charts that would allow the three employees to plan and coordinate events without Julie's constant input. In this plan, Julie would use her contacts to get new business for YES that her employees would then implement.

As Julie thought about Madison's alternatives, she realized that she could continue as is and hope that things improved in the future so that she could get some time off. "Am I overreacting because this is June, my busiest month? Couldn't I take off in the down months?" said Julia out loud. "Wasn't that what you have been saying all these years? I don't see you any less busy in your so-called down months," remarked her husband. As Julie looked up at her husband, she realized that she had an important decision to make.

\section{EXHIBIT A}

\section{Large Event}

\section{Sample Timeline Outline}

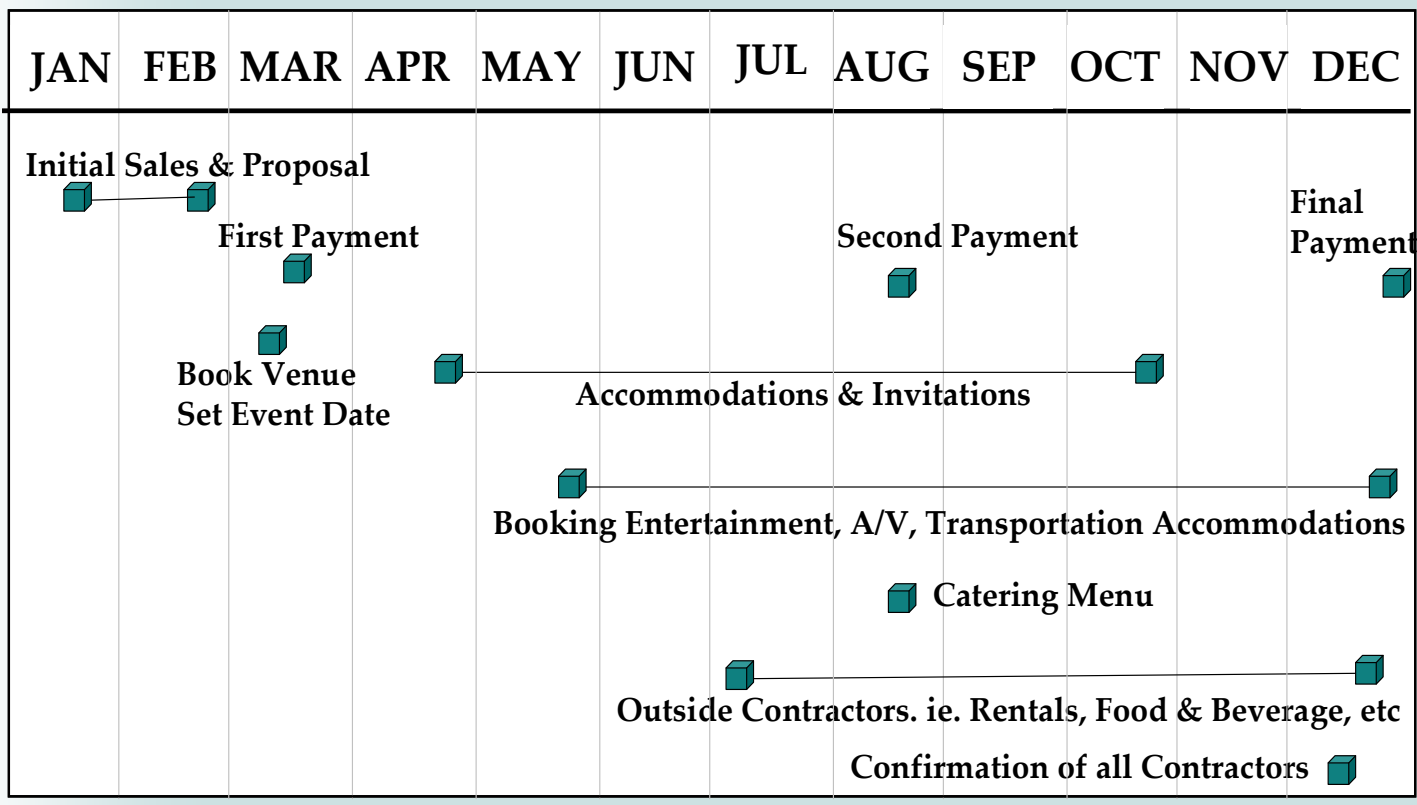

Source: Casewriters' visualization 


\section{EXHIBIT B}

\section{Small Event}

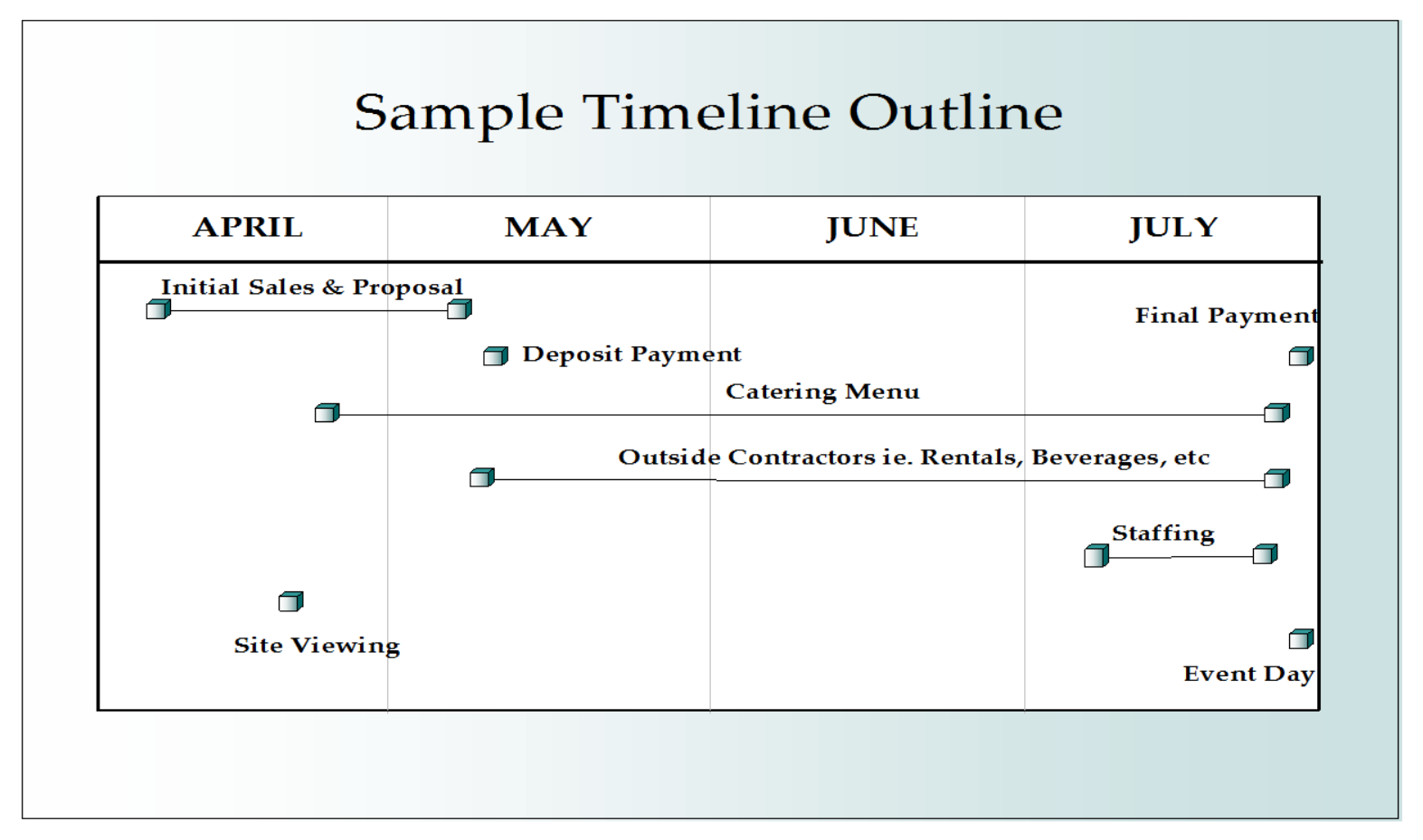

Source: Casewriters' visualization

\section{EXHIBIT C}

\section{Key Recommendations To Grow YES To A Sustainable Business}

\begin{tabular}{|c|c|}
\hline Problem Area & Recommendations \\
\hline Internal Power Struggles & $\begin{array}{ll} & \text { Develop job descriptions with specific tasks assigned to that job } \\
\text { - } & \text { Reward employees commensurate with responsibilities } \\
\text { - } & \text { Cross-train employees on each position } \\
\end{array}$ \\
\hline Division of Tasks \& Duties & $\begin{array}{ll} & \text { Develop a personnel work plan for each project with specific tasks and deadlines } \\
\text { - } & \text { Recognize all employees for their individual contributions to each project } \\
\end{array}$ \\
\hline Billing \& Payments & $\begin{array}{l}\text { - Establish a standard payment schedule (e.g. } 25 \% \text { on signing, } 50 \% \text { two weeks before } \\
\text { event, } 25 \% \text { two weeks after event) }\end{array}$ \\
\hline Organization & $\begin{array}{l}\text { - Hire an additional Event Planner responsible for prospecting, selling, and managing } \\
\text { event plans (contracts, menus, floor plans, rental agreements, etc.), and managing the } \\
\text { event (wait staff, set-up/breakdown, kitchen, etc.). } \\
\text { Hire an Office Associate with responsibility for all office functions, including } \\
\text { answering telephone and e-mails, scheduling appointments, updating weekly payroll, } \\
\text { banking, customer database, etc. }\end{array}$ \\
\hline Communication & $\begin{array}{l}\text { - Maintain a single office folder of all transactions (e.g., e-mails, purchases) related to } \\
\text { each project. } \\
\text { Use project management software (e.g., Microsoft Project) to manage all aspects of } \\
\text { each event. All tasks, with deadlines and assignments to personnel, should be } \\
\text { included. Percentage of accomplishment of each task should be tracked daily. }\end{array}$ \\
\hline
\end{tabular}

Source: Young Event Services 


\section{REFERENCES}

1. Bureau of Labor Statistics, U.S. Department of Labor, Occupational Outlook Handbook, 2006-07 Edition, Arts, Entertainment, and Recreation, on the Internet at http://www.bls.gov/oco/cg/cgs031.htm (visited August 6, 2007)

2. Bureau of Labor Statistics, U.S. Department of Labor, Occupational Outlook Handbook, 2006-07 Edition, Meeting and Convention Planners, on the Internet at http://www.bls.gov/oco/ocos298.htm (visited August 6, 2007)

3. $\quad$ "Event Planning Service. Great at throwing parties? Then turn that talent into a lucrative career.." SmallBizBooks.com. 6 Aug 2007 <http://www.smallbizbooks.com/cgi-bin/smallbizbooks/00073.html>.

4. Fulbright, Jenny. How to Start an Event and Meeting Planning Business. PowerHomeBiz.com. 6 Aug 2007 <http://www.powerhomebiz.com/vo1153/eventplanning.htm>.

5. How to Start an Event Planning Service. Entrepreneur.com. 6 Aug 2007

<http://www.entrepreneur.com/startingabusiness/businessideas/startupkits/article37892.html >.

\section{YOUNG EVENT SERVICES: LIFESTYLE OR LIVING? \\ TEACHING NOTE}

\section{CASE SYNOPSIS}

Young Event Services (YES) is an event planning business serving the New York City/Northern New Jersey market. Julie Young has grown the business as an extension of herself. But as she looks to the future and turning over her business to her daughters, she realizes that she is the business. Can what is a lifestyle for her become a business that provides a living for her daughters? Julie finds an old business plan written by her employee Madison. Will Madison's plan help organize her lifestyle business or will it be too risky?

\section{CASE OBJECTIVES}

The case deals with a woman entrepreneur who finds her business at the transition stage between Stage 1 and Stage 2, albeit being in business for fifteen years. While she is passionate about the business, she also finds herself working long hours and ignoring her family. The case is set at a point in time when a combination of events (a meeting with the family lawyer about the entrepreneur and her husband's will, her husband's insistence that she make a choice between the business as a lifestyle and a living) forces her to take a deep look at her business and make a critical decision about its future. The specific teaching objectives of the case are the following:

1. To identify the challenges an entrepreneur faces in moving the firm from a start-up (where the primary aim is survival) to an efficiently run organization.

2. To explore the problems entrepreneurs (particularly women entrepreneurs) face in balancing work-life demands.

3. To identify organizational design issues (structure, roles, routines) that small entrepreneurial firms face.

\section{CASE PLACEMENT}

The case is suitable for an undergraduate course in entrepreneurship or small business management. Ideally, the case should be taught toward the middle of the course where organizational design and human resource management practices are discussed. Alternatively, the case can be used in a seminar or workshop that focuses on women entrepreneurs and the challenges they face.

\section{TEACHING PLAN}

The five questions listed below should be used to structure the class discussion of the case. The linear flow of the questions - from a macro perspective of the event planning business to the micro focus on YES's issues - 
lends itself to a logical discussion and yet allows the instructor to make detours into related areas. Exhibit 1 presents an overview of the teaching plan for the case for a 75-minute class.

\section{DISCUSSION QUESTIONS}

1. How does an event planning business operate? Is YES successful?

2. What are the issues confronting Julie Young?

3. Why are these issues important for both Julie Young and YES?

4. Examine the pros and cons of the choices facing Julie Young at the end of the case.

5. What would you recommend Julie Young do? Why?

\section{SUGGESTED ANSWERS TO DISCUSSION QUESTIONS}

\section{How does an event planning business operate? Is YES successful?}

It is important that the instructor spend some time initially in ensuring that students understand the nature of the event planning business because this is key to identifying the issues that Julie Young faces. Event planners, as the title indicates, plan and implement events for their clients. These events may include personal social events such as birthday parties, weddings, Bar Mitzvahs, etc. as well as larger corporate events such as charitable golf outings and product launches. Personal social events is a booming market because baby boomers find themselves hard pressed for time to plan these events and are willing to hire professionals for this job. Six percent of the 43,000 meeting and convention planners (around 2,580) were self-employed, such as Julie Young. Event planners made money in a variety of ways - by charging a flat fee for the event (a practice that Julie Young followed) or per hour, or taking a percentage of the budget, and through markups on food and personnel used in the event.

Students must understand that Julie Young is doing quite well as the owner of YES. The business has been in existence for 15 plus years, generates revenues of $\$ 350,000$ in its most recent year, employs three people in addition to the owner, and presumably gives Julie Young a reasonable living. It is important to keep in mind that the $\$ 350,000$ in revenues for YES comes from three sources: fees for planning events, markup on food and other costs incurred on behalf of the customer, and the flat $\$ 30$ per hour billed for personnel hired to work events. The case states that event-planning companies have gross profit margins between 30-40\%. This means that YES' gross margins are between $\$ 105,000$ and $\$ 140,000$, if not more. From this, Julie Young has to pay wages to her three employees as well as rent and utilities for her office. Of the three employees, Madison is an intern student from a local university and Katie works only 1-2 days a week. This means that Kim is the only full-time regular employee who is paid (presumably) market wages. It is clear that Julie Young is doing quite well financially.

\section{What are the issues confronting Julie Young?}

While Julie Young is the owner of a successful event planning business (as indicated in Q1. above), clearly there are issues confronting her. The instructor can approach this discussion by posing a larger question to the class:

Assuming that Julie Young makes a net income of around \$60,000 per year (based on gross margin of, say, \$105,000 from Q1. above), can she do better? Is anything holding her and YES back?

The event planning industry is growing, particularly the personal social event segment. YES operates a seasonal business, with April through June (3 months) and October through December (3 months) being her peak. In other words, for six months in the year, she averages a little more than $\$ 38,000$ per month $(\$ 230,000 / 6)$. In the non-peak six months, she averages $\$ 20,000$ per month $(\$ 120,000 / 6)$. Some students are likely to point out that if YES does a lot of birthdays and Bar Mitzvahs, Julie Young should try to get more business during the off-peak months because these events are not seasonal such as weddings. There is clearly a great market opportunity to increase business during these months. 
As the case indicates, a well-run event brings positive word of mouth publicity and referrals ( 25 for a successful event). The case seems to indicate that YES has a positive reputation in the field. This again indicates that the potential for YES and Julie Young is immense.

The instructor can pose the following question to the class:

\section{Do you think Julie Young is in a position to leverage the market opportunity for growth?}

Students are likely to point out that time management is the key issue confronting Julie Young. She seems to be micromanaging her business. As evidence, the instructor should point out to the opening monologue in the case where Julie finds herself working at 4:30 a.m. Why is she wondering about things such as placing orders for baseball cubes, organizing menu choices, scheduling airport picks ups, etc.? Should she be doing these routine activities? Isn't her time better spent drumming up new business using her market goodwill and extensive contacts? In addition, she does not have free time to spend with her family. While the separation of work and personal life is often a difficult decision and a common problem facing entrepreneurs and small business owners (that students are likely to identify), the instructor should point out that YES is a 15+-year-old company and not a start-up. Shouldn't the owner of such a company have more free time than what Julie Young currently has?

The negative effects of Julie Young's micromanaging and poor time management shows in the following:

- $\quad$ her husband's unhappiness about Julie's lack of time for the family

- $\quad$ her husband's concern that there may not much of a business for Julie to pass on to their daughters

- Invoices from 2005 (unpaid?) lying around in her office

- $\quad$ sleepless nights that may very well affect Julie's health

\section{Why are these issues important for both Julie Young and YES?}

The identification of the problems in Q2 above leads to the question of why these issues are important and deserve Julie Young's immediate attention. The instructor should reiterate that Julie Young does not see potential lost business as an issue. She proudly tells her lawyer that her business grossed $\$ 350,000$ last year. The class is likely to be divided on this issue. If you are making around $\$ 60,000$ a year doing something that you love, then why worry about potential lost opportunities? Some may point out that if Julie Young is putting in 15-20 hours a day in her business, isn't she earning a little more than minimum wage?

While the issue of earning an income may lead to a spirited debate, the instructor has to steer the discussion to the key question: if Julie and her husband want to pass on YES to their daughters, isn't the business too dependent on Julie for it to succeed under new management? Granted that event planning is a referral and contact-based business, yet, shouldn't Julie organize her business better?

\section{Examine the pros and cons of the choices facing Julie Young at the end of the case.}

Apart from the "do nothing" option that Julie has, there are two options identified in the case that need further examination. The options were first detailed in intern student, Madison Beech's business plan for YES. The instructor should devote adequate time to flesh out these options clearly.

The first option is to hire a full-time second in command who would be the chief operating officer (COO) to Julie Young's CEO. The biggest advantage of this option is that a $\mathrm{COO}$ would free much of Julie Young's time. A COO, whether it is Madison Beech or Kim or an outside hire would be responsible for handling the details of specific events leaving Julie Young to focus on business development. Since the operational side of event planning lends itself to flow charting (such as the ones in the case), the $\mathrm{COO}$ can quite easily coordinate these events with the help of the staff. 
The downside of hiring a COO is the cost. This new position will cut into Julie's income because of the additional salary. This is a common dilemma that small business owners face. Can I afford to hire an additional person? Assuming that the hiring is from the inside (i.e., Madison or Kim), it is possible that the additional cost incurred by Julie would be around $\$ 30,000$ (the additional salary for Madison or Kim commensurate with the position of COO). Can Julie bring in additional business to offset the loss of $\$ 30,000$ of her income? In reality, given her margins, Julie should bring in $\$ 75,000$ or so in new business. It seems possible, given YES's standing in the market.

The second option looks at creating an organizational structure for YES. This means creating an organizational chart that delineates responsibilities, developing job descriptions that identify each employee's role, and coming up with organizational routines for paying bills, coordinating activities, etc. It is important for the instructor to point out that in option 1 above it is likely that the $\mathrm{COO}$ would end up doing all of the items identified in option 2.

Exhibit $\mathrm{C}$ in the case presents a list of operational issues for YES that Madison Beech's business plan identified. Option 2 would address all of these issues. The biggest advantage of this option is that it would save Julie Young the cost of hiring a COO. In addition, job descriptions, organization chart, and routines would free Julie Young's time to prospect for new business and enjoy some free time. Exhibit $\mathrm{C}$ calls for 2 new hires - an event planner to develop new business as well as coordinate events and an office associate to handle the administrative work. We do not know what the specific responsibilities of the current employees are. It is possible that Julie Young can get away with hiring one additional person who will act as the event planner. As in option 1, YES needs to generate additional business to offset the increased cost of a new hire.

\section{What would you recommend Julie Young do? Why?}

The instructor should, once again, reiterate that option 1 is likely to include some, if not all, of option 2. In other words, a COO is likely to instill structure in YES. Option 2 appears to make more sense simply because what YES needs is structure. Setting up the structure is a one-time activity beyond which the value of a COO becomes questionable. Creating a structured organization and hiring an event planner would achieve Julie Young's objectives. She would have time to get additional business and grow YES and more free time to spend with her family. In addition, documenting business routines and creating a well-designed organization would make it easier for Julie Young to pass on the business to her daughters.

\section{SUGGESTED ASSIGNMENT}

A good out-of-class assignment would be a report that addresses the issues facing YES and recommendations for Julie Young. The report should contain the following additional items:

- $\quad$ an organization chart

- job descriptions, assuming that an event planner is hired in addition to the current employees 


\section{EXHIBIT 1}

\section{Teaching Plan}

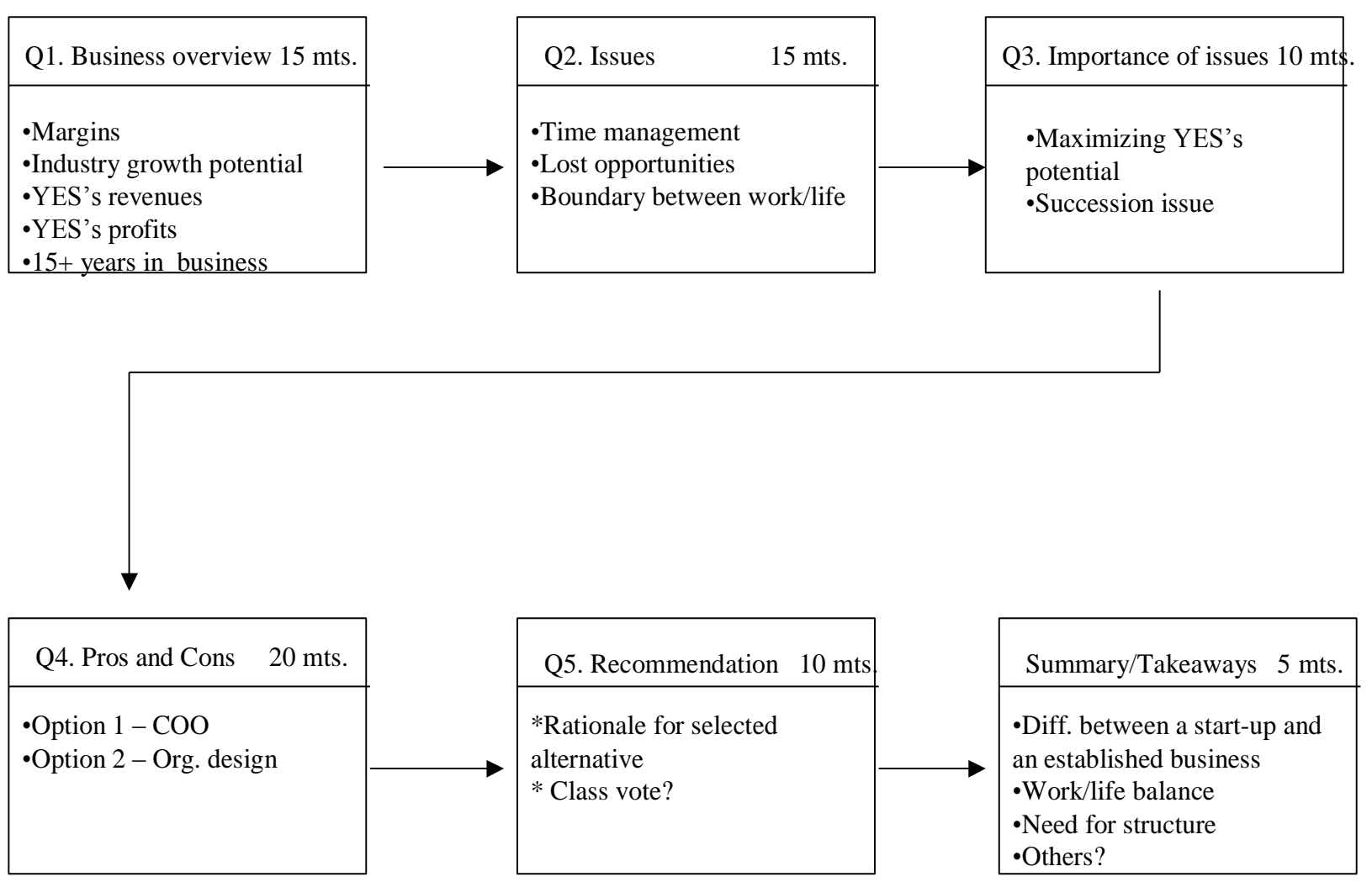

